\title{
Bank Failure: A New Approach to Prediction and Supervision
}

\author{
Calvin W. H. Cheong (Corresponding author) \\ Faculty of Business, Design and Arts, Swinburne University of Technology Sarawak \\ Jalan Simpang Tiga, 93350 Kuching, Malayis \\ Tel: 60-82-260-996 E-mail: ccheong@swinburne.edu.my \\ Sockalingam Ramasamy \\ Department of Accounting, Banking \& Finance, School of Business, Monash University \\ Malaysia \\ Jalan Lagoon Selatan, 47500 Selangor, Malaysia \\ Tel: 60-3-5514-4931 E-mail: r.sockalingam@monash.edu
}

Received: Jan. 9, 2019 Accepted: April 8, 2019 Published: June 1, 2019

doi:10.5296/ajfa.v11i1.14455 URL: https://doi.org/10.5296/ajfa.v11i1.14455

\begin{abstract}
Bank failures are costly to customers and the wider market. Prevention is always better than cure but in light of recent economic downturns, it has become increasingly difficult for regulators to allocate more resources towards in-depth monitoring of banking practices. In this paper, we construct a tool that is able to predict bank failures ahead of time with reasonable accuracy. Through a logistic regression on a matched sample of 536 failed and non-failed US banks, we determine the financial indicators that most accurately predicts bank failure. From the regression, we construct a Bank Health Index that assesses a bank's propensity to failure. In-sample and out-of-sample tests show that our model is about $90 \%$ accurate two years prior to failure, and $95 \%$ accurate the year before failure. The accuracy and efficiency of the model and index provides a more efficient and effective tool for assessing a bank's propensity to failure besides requiring far less resources. With these methods, regulators will be able to take preventive measures at least one year before failure, saving the economy millions if not billions in the process.
\end{abstract}

Keywords: Bank failure, Financial crisis, Failure prediction, Commercial banks, Early warning system 


\section{Introduction}

Are current risk management and monitoring devices adequate to avoid bank failures in light of increasing globalisation, market integration, and the use of innovative (and sometimes questionable) financial innovations used by banks and other financial institutions? Despite the well-meaning objectives of the Basel Capital Accord - now in its third iteration - many banks the world over have failed as a result of a number of financial crises such as the Asian Financial Crisis of 1997 (AFC) and the Global Financial Crisis of 2007 (GFC). Governments and central banks around the world resorted to billion-dollar liquidity injections and bailouts to avoid a severe tightening of credit and losses to customer deposits in their respective economies. Wary of bank failures, regulators have responded by introducing a multitude of risk management tools and benchmark financial indicators to ensure that banks remain adequately capitalised to absorb losses arising from credit, operational, and market risks. But as the large number of bank failures resulting from the recent crises shows, our ability to predict bank failure is severely lacking. If we are able to understand the factors related to bank failure, we could develop predictive methods to distinguish between sound and troubled banks (Thomas, 1991). With sufficient accuracy, these predictive methods will enable regulators to detect problems much allowing for remedial action to mitigate the risk of bank failure.

A number of works in predicting bank failure have been conducted (see Beaver, 1996; Altman 1968; Agarwal and Taffler, 2008; Andersen, 2008; Atiya, 2001; Balcaen and Ooghe, 2005; Bell and Pain, 2000; Bongini, Laeven and Majnoni, 2002; and Brossard, Ducrozef and Roche, 2007 for example) but despite the tremendous methodological developments in bank failure prediction models, bank failures persist; a strong indication of the inadequacy of existing models. Thus exists a need for a rethink and redesign of bank health evaluation using a new set of indicators, and subsequently, a unified device or tool that can be continuously used to monitor the soundness of individual banks.

In this study, we derive these key bank health indicators from 536 recent examples of bank failures resulting from the GFC in the U.S. by observing the changes to CAMEL (Capital, Asset, Management, Earnings and Liquidity) framework indicators in the 4 years leading up to the bank's failure. By estimating a logit model on a year by year basis, we find that the indicators that can best distinguish between healthy and unhealthy banks are Tier 1 capital ratio, impaired loans to equity, rate of loan growth, return on average assets, net interest margin, net loans to total assets, loans to deposits ratio, and impaired loans to gross loans. In-sample tests show that our model has a reasonably high chance of correctly predicting bank failure in the year of failure $(89.86 \%)$ and the preceding year $(81.30 \%)$. Out-of-sample tests validate our findings; showing a perfect accuracy of predicting bank failure in the year of failure (100\%) and nearperfect accuracy in the preceding year (95.38\%), with minimal Type I and II errors. On the basis of these indicators, we then construct a "Bank Health Index" to develop a more efficient method of assessing the soundness of a bank relative to other banks as well as the entire banking system. We used a sample of 20 domestic and foreign banks operating in Malaysia for this purpose as Malaysia's banking regulatory system has been regarded as one of the best in the world. 
Our findings contribute to extant literature in a few ways. First, our model's accuracy in correctly predicting bank failure surpasses the predictive power of other failure-prediction models in the literature, with minimal error. Second, the simplicity of our variables and methods used in deriving the model makes ours more efficient and practicable for regulators and market observers alike. Finally, the "Bank Health Index" provides a quick and easy way for regulators to identify potentially unhealthy banks and take immediate remedial action at least one year before failure. The rest of this paper is structured as follows. Section 2 provides a review of relevant literature. Section 3 presents the theoretical framework and methodology used in this study. We present our findings and discussion in Section 4. Section 5 concludes.

\section{Literature Review}

Central to the existence of the modern economy is the role banks play as the primary intermediary for the distribution of funds. It is thus in the best interests of the regulators to avoid the possibility of a bank failure. But despite the regulators' best efforts, bank failures still occur. And when they do, the repercussions are far-reaching. In order to detect and prevent bank failure, we must first identify the aspects of bank operations and fund flows that are critical to the survival of the bank. The following discussion on relevant indicators is based on the CAMEL framework prescribed by central bankers and the International Monetary Fund (Gersl and Hermanek, 2006).

The first is its highly leveraged nature of business that is reliant on loans, advances and shortterm investments, as assets that stem from liabilities held by the bank (e.g. deposits). The creation of assets from liabilities is simply a redistribution of wealth and is a system that has worked for centuries. However, an economic downturn may cause a rise in loan defaults, or falling asset values. Banks in response would have to make higher loan loss provisions and be prepared to write-off bad loans as collateral values are insufficient to cover bad loans; a prime indicator of insolvency (Kunt and Detragiache, 1998), and poor asset quality (GonzalezHermosillo et al., 1996). Periods of economic growth meanwhile would see the growth of the banking system outpacing that of the country and even inflation. The exuberance may result in questionable lending practices and poor asset quality, creating potential loan repayment and recovery problems in the future (Bell and Pain, 2000; Jimenez and Saurina, 2006; Berg and Hexeberg, 1994; Logan, 2003). Studies (e.g. Foos et al., 2010; Andersen, 2010) have shown that aggressive lending during growth periods often lead to defaults two to four years after, resulting in a cooling and declining period of banking growth that may even amount to negative growth.

Even if steps to ensure the quality of their loans and assets were taken, defaults inadvertently occur, hence the need for loan loss reserves to act as a buffer against writing down the bank's capital (Anglomkiew et al., 2008; Floro, 2010). During severe market downturns, loan loss reserves are insufficient; capital erosion becomes inevitable until loan losses significantly outweigh available capital resulting in insolvency and subsequently, failure. Common indicators of bank capital adequacy are the core capital ratio and the risk-weighted capital ratio, prescribed by the Basel II (and III) Capital Accords. These ratios are a good measure to determine the strength of a bank as adjustments for credit risk arising from off-balance sheet 
items have been considered in these ratios (Estrella, 2000). Thus, a greater amount of capital improves a bank's chance of survival (Andersen, 2008).

Another key aspect for bank survivability is liquidity. Bank liabilities, primarily stemming from customer deposits, are generally short term in nature vis-à-vis its assets that are longer term, thereby creating liquidity mismatch. As depositors have a right to withdraw funds without notice, banks must maintain sufficient liquidity at all times. But when revenue generated from loans and other assets fall short of liquidity demands, or when banks fail to convert liquid assets into cash on time, the liquidity shortage might result in a bank run (Lanine, 2005; Reed and Gill, 1989). Close observation of the loan-to-deposit ratio and the net-loans-to-assets ratio may provide indication of the bank's level of liquidity.

Bank profitability is reflected in the net interest margin (NIM). However, as NIM is dependent on the rate of interest charged on loans as well as the interest cost of sourcing loanable funds for distribution, high NIMs may be indicative of excessive risk taking and imprudent lending practices (Evans et al., 2000). During the AFC and GFC, banks dependent on short-term money market funds saw market interest rates rising to their detriment, reducing NIMs from two fronts: higher cost of funds, and greater loan defaults due to higher repayments. Extraordinarily high NIMs are possibly indicative of potential failure as banks hold a large portfolio of high-yield risky, as well as interest-bearing assets (Ross et al., 2007). High NIMs may also precede failure much earlier and fall significantly immediately before failure due to higher loan loss provisions (Despagne, 2010). Regardless, inclusion of NIMs into a failure-prediction model should provide additional explanatory power.

The literature is replete with off-balance sheet items (OBS) and short-term wholesale funding and its association with bank failures. Greater amounts of these assets are associated with a greater probability of failure. Similarly, studies (e.g. DeYoung and Toma, 2012; Allen and Jagtiani, 2000; Clark et al., 2007) have shown that reliance on volatile non-traditional income sources (i.e. non-interest income) such as insurance income, fees, commissions and other noninterest bearing income are associated with higher probabilities of bank distress. Failed banks are expected to have been more aggressive in their business diversification strategies and to have sought out the opportunities arising from scope deregulation. Banks have also diversified their sources of funding into non-traditional sources such as short-term money market funds. Given the volatile nature of these funding sources, over-reliance on such funds could place the bank in a risky liquidity position. Observation of the ratio of wholesale short-term liabilities to liquid assets (WST) is thus warranted.

But even with hawkish monitoring over these indicators, bank failures can and do occur as a result of inefficient bank management exemplified through poor operations, management, monitoring of loans and sub-optimal use of resources. Often observed through return on average assets (ROAA), management efficiency can be translated as the profits generated through efficient usage of assets. Operational efficiency on the other hand, can be observed through the cost to income ratio (CIR); an indication of how well the bank has kept growth of revenues ahead of rising expenses (Rahman, 2004). 


\section{Theoretical Framework and Methodology}

\subsection{Explanatory Variables}

Based on the literature review in Section 2, the variables observed in this study, their definitions and their expected impact on the propensity of bank failure is summarised in Table 1 below.

Table 1. Definition of Variables

\begin{tabular}{|c|c|c|}
\hline Variable & $\begin{array}{c}\text { Variable } \\
\text { abbreviation }\end{array}$ & $\begin{array}{l}\text { Expected } \\
\text { sign }\end{array}$ \\
\hline \multicolumn{3}{|l|}{ Capitalization } \\
\hline Total Capital Ratio (Tier 1 + Tier 2 capital / Risk-weighted assets) & TOTCAP & $(-)$ \\
\hline Core Capital Ratio (Tier 1 capital / Risk-weighted assets) & TIERCAP & $(-)$ \\
\hline \multicolumn{3}{|l|}{ Asset Quality/Credit Risk } \\
\hline Impaired loans / Gross loans & IMPL & $(+)$ \\
\hline Loan loss reserves & LLR & $(+)$ \\
\hline Impaired loans / Total equity & IMPE & $(+)$ \\
\hline Loan Loss Reserves / Impaired loans & LLIMP & $(+) /(-)$ \\
\hline Loan growth (year-on-year) & LOANGROWTH & $(+)$ \\
\hline Asset growth rate (year-on-year) & AGR & $(+)$ \\
\hline \multicolumn{3}{|l|}{ Earnings or Profitability } \\
\hline Net income / Average equity & ROAE & $(-)$ \\
\hline $\begin{array}{l}\text { Net interest margin (NIM): (Net interest income - Net interest expense } \\
\text { / Total earning assets) }\end{array}$ & NIM & $(-) /(+)$ \\
\hline \multicolumn{3}{|l|}{ Liquidity } \\
\hline Net loans / Total assets & NETLOANS & $(+)$ \\
\hline Loans to deposit ratio & LOANDEP & $(+)$ \\
\hline Liquid funds (cash and short-term assets) / Total assets & LIQ & $(-)$ \\
\hline \multicolumn{3}{|l|}{ Reliance On Fee Income } \\
\hline Non-interest fee income / Total income & INTEREST & $(+)$ \\
\hline \multicolumn{3}{|l|}{ Relience on off-balance sheet items } \\
\hline Off-balance sheet items / Total assets & OBS & $(+)$ \\
\hline \multicolumn{3}{|l|}{ Reliance on short-term wholesale funds } \\
\hline Volatile Wholesale short-term liabilties / Liquid assets & WST & $(+)$ \\
\hline \multicolumn{3}{|l|}{ Management Quality / Efficiency } \\
\hline Return on average assets & ROAA & $(-)$ \\
\hline Cost to income ratio & CIR & $(+)$ \\
\hline
\end{tabular}

We obtained a sample of 536 U.S. banks between the years 2004 to 2010, with an equal number of failed and non-failed banks, matched by total assets, from the Bankscope database. Because the U.S. saw a large number of bank failures during the GFC, it provides an ideal setting to the predictive power of our model. Malaysia alongside many other countries around Asia on the other hand, was relatively unscathed. Even during the AFC, Malaysia being one of the worsthit did not see any bank failures due to rescue packages and bank mergers and acquisitions. 
Because our purpose is to study the predictability of bank failure a priori, we collected data on the variables listed in Table 1 for the years before the bank failed. We denote the year of failure as Year, and the preceding years as Year-1, Year-2, Year-3, and Year-4; observing changes to the variables over the years for any significant changes or trends. Identifying the variables with considerable explanatory power is simply a matter of determining the statistically significant differences in the mean values between the failed and non-failed sample (Vilen, 2010).

\subsection{Empirical Model}

We use a logistic regression model to identify the financial ratios that can most effectively discriminate between failed and non-failed banks in the most reliable (Frydman et al, 1985; Marais et al, 1984; Ohlson, 1980; Casey and Bartczak, 1985; Zavgren, 1985; Glezakos et al, 2010) manner. The model specification is:

$$
Y_{i}=\beta_{0}+\sum_{i=1}^{k} \beta_{i} X_{i}
$$

where $Y_{i}$ is a binary variable with a value of " 1 " for a failed bank and " 0 " for a non-failed bank, while $X_{i}$ is a vector of the explanatory variables that have been determined to possibly have the strongest explanatory power in predicting bank failure. If the probability of bank $i$ failing is $P\left(Y_{i}=1\right)=\hat{p}$ and the probability of bank $i$ not failing is $P\left(Y_{i}=0\right)=1-\hat{p}$, then

$$
\hat{p}=\frac{e^{\beta_{0}+\sum_{i=1}^{k} \beta_{i} X_{i}}}{1+e^{\beta_{0}+\sum_{i=1}^{k} X_{i}}}
$$

Logit models are sensitive to extreme multicollinearity (Balcaen and Ooghe, 2005) and thus, Espahbodi (1991) advocates the use of more than one measure in studying bank health to avoid issues related to multicollinearity. As we seek to construct a model as an early warning system, we estimate the regression for the year of failure as well as for each of the four years preceding failure. To test the reliability and external validity of our method, we re-estimate the logit model using a hold out sample (Jones, 1987).

\subsection{Constructing the Bank Health Index}

To construct the "Bank Health Index", we first define the value ranges of the statistically significant variables from the logit estimates by computing $95 \%$ confidence intervals around the mean values of each variable for the failed and non-failed sample. We only compute value ranges for Year $_{-1}$ and Year $_{-2}$ as the predictive power of variables diminish beyond two years preceding failure (Espahbodi, 1991). This confidence level for the variables is constructed base on the following expression.

$$
\text { Upper bound }=\bar{x}+1.96 * \frac{s}{\sqrt{n}} \quad ; \quad \text { Lower bound }=\bar{x}-1.96 * \frac{s}{\sqrt{n}}
$$




\section{Macrothink

The computed value ranges will be further classified into a risk continuum ranging from critical to excellent depending on the correlation of the significant variable ratios to failure.

The value ranges computed above need to be interpreted with respect to each of the ratios. For example, for variables negatively related to bank failure such as capitalization ratios, a higher ratio indicates better health. Hence, a ratio falling below the "failed" range will be categorised as "critical" while a ratio value above the "non-failed" range is categorised as "excellent". For variables positively related to bank failure such as impaired loans to total equity (IMPE), a ratio above the "failed" range would be categorised as "critical" while a ratio below the "non-failed" range is categorised as "excellent".

We then convert the value ranges into scores (0 to 10). To ensure an even spread, the median value of each variable is given a score of 5. For variables that are negatively related to failure, any value that falls above the median obtained a score higher than 5 and the rest obtained scores lower than 5. With $x$ as the variable value and $m$ as the median value for the variable, the score is calculated as follows:

$$
\begin{aligned}
& \text { if } x<m \text { then the score for the bank }=5-\left(\frac{m-x}{m-\min } * 5\right) \text {; and } \\
& \text { if } x>m \text { then the score for the bank }=5+\left(\frac{x-m}{\max -m} * 5\right) \text {. }
\end{aligned}
$$

For example, if TOTCAP had a maximum of $25 \%$, a minimum of $0 \%$ and a median of $13 \%$, the score for the bank is $=5-\left(\frac{13-x}{13-0}\right) * 5$. If $x<13$ or if $x>13$ then the score for the respective bank is $=5+\left(\frac{x-13}{25-1} * 5\right)$.

Thus, a bank with a TOTCAP ratio below the median would receive a score below 5 while a bank with a ratio above the median would receive a score higher than 5 . Hence, the higher the TOTCAP ratio, the higher the score a bank achieves. The scores for the variables which have a positive correlation with bank failures is calculated as follows;

$$
\begin{aligned}
& \text { if } x<m \text {, then the score for the bank }=5+\left(\frac{m-x}{m-\min } * 5\right) \text {; and } \\
& \text { if } x>m \text {, then the score for the bank }=5-\left(\frac{x-m}{\max -m} * 5\right) \text {. }
\end{aligned}
$$

That is to say, the lower the ratio, the better the bank's health. Hence, a bank with a lower $x$ would receive a higher score than a bank with a higher $x$.

The calculation of scores for the variable LOANGROWTH, poses a problem as too high or too low a ratio would point to failure. The score for LOANGROWTH is thus calculated as follows:

$$
\text { if } x<m \text {, then the score for the bank }=10-\left(\frac{m-x}{m-\min } * 10\right) \text {; and }
$$




$$
\text { if } x>m \text {, then the score for the bank }=10-\left(\frac{x-m}{\max -m} * 10\right) \text {. }
$$

Here, the median value gets a score of 10. Any value further away from the median in either direction would result in a lower score.

With the scores computed, we then construct a micro-soundness index for each bank as well as a macro-soundness index for the entire banking industry. The soundness index will consist of the five main aspects of bank health prescribed by the CAMEL framework i.e. capitalisation, asset quality, management efficiency, earnings and liquidity. The micro-soundness index is constructed by summing the component scores for each health aspects of the bank. Where a health component is represented by more than one variable (e.g. asset quality), the component score is calculated by taking an average of the scores. With a maximum score of 10 for each significant variable, the maximum total health score will be 50 . This score will then be converted into a scale ranging from 0 to 100 . In this instance, the maximum score of 50 would be defined as 100 on the health scale, which will be the soundness index for individual banks. The macro-soundness index is constructed by taking the summation of individual bank health scores, weighted by the ratio of total assets of the bank and the total assets of the banking industry. The weighted average health score would be on a continuum of 0 to 100 , with 0 representing poor health and 100 excellent health.

\section{Analysis and Findings}

\subsection{Descriptive Statistics}

To determine the independent variables that have the greatest explanatory power to predict bank failure, we first determined whether there are statistical significant differences in the mean values of the two samples (Vilen, 2010) on a year-by-year basis, beginning in Year-4 until Yearo, by observing changes to the financial ratios over the years for the failed and non-failed banks. We then conduct a student $t$-test at the $1 \%$ level of significance (Note 1). We present these in Tables $2-7$ below. Since not all variables were statistically significant in all the five years, we omit those that: (1) did not show a statistically significant difference in any of the years; (2) showed significant difference only in the year of failure; and (3) showed significant difference in just one of the years. The variables employed in this study were strictly required to show a statistically significant difference between the two data samples (failed and non-failed banks) (Note 2). For brevity purposes, we only discuss the variables that from the $t$-test, has sufficient power to predict bank failure. 
Table 2. Descriptive Statistics and $t$-test for Capital Adequacy

\begin{tabular}{|c|c|c|c|c|c|c|c|}
\hline \multirow{2}{*}{$\begin{array}{c}\text { Capital } \\
\text { Adequacy }\end{array}$} & \multicolumn{3}{|c|}{ Non-Failed Banks } & \multicolumn{3}{|c|}{ Failed Banks } & \multirow{2}{*}{$t$-stat } \\
\hline & Mean & Std. Dev. & $\%$ Change & Mean & Std. Dev. & $\%$ Change & \\
\hline TIERCAP0 & 16.126 & 11.604 & $-3.19 \%$ & 5.800 & 4.129 & $44.58 \%$ & $13.69 * * *$ \\
\hline TIERCAP-1 & 16.658 & 16.824 & $2.77 \%$ & 10.465 & 3.189 & $29.59 \%$ & $5.91 * * *$ \\
\hline TIERCAP-2 & 16.208 & 11.375 & $-6.75 \%$ & 14.863 & 15.841 & $6.00 \%$ & 1.12 \\
\hline TIERCAP-3 & 17.381 & 13.748 & $-1.90 \%$ & 14.022 & 18.080 & $26.04 \%$ & $2.41 * * * *$ \\
\hline TIERCAP-4 & 17.717 & 15.642 & & 18.958 & 39.822 & & 0.47 \\
\hline TOTCAP0 & 17.291 & 11.519 & $-2.61 \%$ & 7.023 & 4.317 & $40.11 \%$ & $13.64 * * *$ \\
\hline TOTCAP-1 & 17.755 & 16.711 & $2.75 \%$ & 11.726 & 3.150 & $26.61 \%$ & $5.79 * * *$ \\
\hline TOTCAP-2 & 17.279 & 11.280 & $-6.48 \%$ & 15.978 & 15.786 & $5.31 \%$ & 1.09 \\
\hline TOTCAP-3 & 18.475 & 13.655 & $-1.81 \%$ & 15.172 & 18.002 & $24.42 \%$ & $2.39^{* * *}$ \\
\hline TOTCAP-4 & 18.817 & 15.535 & & 20.074 & 39.668 & & 0.48 \\
\hline
\end{tabular}

The table presents the descriptive statistics, percentage change in mean values and $t$-statistics for the Capital Adequacy variables from Year-4 to Yearo. TIERCAP is the core capital ratio and TOTCAP is the total capital ratio. Full variable definitions are in Table 1. ***,**, and * indicate significance at the $1 \%, 5 \%$, and $10 \%$ level respectively.

Table 2 presents the descriptive statistics, the percentage change in mean values and $t$-statistics for the Capital Adequacy variables in this study from Year-4 to Year 0 . From Table 2, we can see that TIERCAP and TOTALCAP for non-failed banks remained relatively constant even until Yearo. Failed banks in contrast exhibited falling TIERCAP and TOTALCAP values from year to year; falling below the minimum of $8 \%$ in the year of failure. These changes seemingly support the proposition that failed banks are poorly capitalised i.e. they have a much smaller buffer against potential losses arising from credit or economic risk. We also recorded statistically significant differences between the mean TIERCAP and TOTCAP values of failed and non-failed banks, allowing both to be reasonable indicators of bank health.

Table 3 presents the descriptive statistics, percentage change in mean values and $t$-statistics for the Asset Quality variables in this study from Year-4 to Yearo. Impaired loans for non-failed banks have risen steadily over the years (up to 21 times of total equity in Yearo). IMPE for failed banks on the other hand, rose exponentially up to 227 times in Yearo. $t$-tests also reveal a statistically significant difference in IMPE values between both samples - an indicator of their suitability in distinguishing bank failure. Similar trends were observed for impaired assets to gross loans (IMPL). Failed banks recorded tremendous growth in this regard, leading up to Yearo; suggestive of the variable's power in explaining bank failure. The trend observed for LOANGROWTH is consistent with our earlier discussion. Failed banks were lending aggressively in the years prior to failure, finally leading to negative growth in the year of failure as a result of loan defaults. While a similar trend is observed for non-failed banks, the rate of change was more subdued. Asset growth rate (AGR) displayed a similar trend and statistical significance over the years. The $t$-statistics support the proposition that high loan growths as well as asset growth in preceding years are indicators of failure. 
Table 3. Descriptive Statistics and $t$-test for Asset Quality

\begin{tabular}{|c|c|c|c|c|c|c|c|}
\hline \multirow{2}{*}{ Asset Quality } & \multicolumn{3}{|c|}{ Non-Failed Banks } & \multicolumn{3}{|c|}{ Failed Banks } & \multirow{2}{*}{$t$-stat } \\
\hline & Mean & Std. Dev. & $\%$ Change & Mean & Std. Dev. & $\%$ Change & \\
\hline IMPE0 & 21.251 & 35.105 & $60.48 \%$ & 227.144 & 214.575 & $320.69 \%$ & $15.47 * * *$ \\
\hline IMPE-1 & 13.242 & 22.221 & $91.46 \%$ & 53.993 & 68.580 & $297.95 \%$ & $9.24 * * *$ \\
\hline IMPE-2 & 6.916 & 13.124 & $78.62 \%$ & 13.568 & 19.428 & $148.21 \%$ & $4.64 * * *$ \\
\hline IMPE-3 & 3.872 & 5.896 & $22.12 \%$ & 5.466 & 7.990 & $21.28 \%$ & $2.62 * * *$ \\
\hline IMPE-4 & 3.171 & 4.656 & & 4.507 & 7.179 & & $2.552 * * *$ \\
\hline IMPL0 & 2.861 & 4.065 & $68.01 \%$ & 13.898 & 8.887 & $162.14 \%$ & $18.46^{* * *}$ \\
\hline IMPL-1 & 1.703 & 2.174 & $74.86 \%$ & 5.302 & 5.514 & $229.70 \%$ & $9.93 * * *$ \\
\hline IMPL-2 & 0.974 & 1.748 & $66.90 \%$ & 1.608 & 2.217 & $135.13 \%$ & $3.67 * * *$ \\
\hline IMPL-3 & 0.583 & 0.838 & $18.52 \%$ & 0.684 & 0.964 & $20.99 \%$ & $1.29 * *$ \\
\hline IMPL-4 & 0.492 & 0.707 & & 0.565 & 0.927 & & $1.02 *$ \\
\hline LOANGROWTH0 & 3.834 & 19.646 & $-64.29 \%$ & -6.112 & 23.072 & $-136.34 \%$ & $5.36 * * *$ \\
\hline LOANGROWTH-1 & 10.734 & 25.111 & $-40.30 \%$ & 16.821 & 63.718 & $-49.08 \%$ & $1.45 * *$ \\
\hline LOANGROWTH-2 & 17.981 & 51.372 & $-8.68 \%$ & 33.033 & 71.026 & $-1.49 \%$ & $2.81 * * *$ \\
\hline LOANGROWTH-3 & 19.690 & 66.928 & $45.00 \%$ & 33.533 & 50.839 & $-27.76 \%$ & $2.69 * * *$ \\
\hline LOANGROWTH-4 & 13.580 & 21.365 & & 46.420 & 101.342 & & $5.18 * * *$ \\
\hline LLR0 & 1.676 & 0.826 & $17.25 \%$ & 3.572 & 2.245 & $7782.00 \%$ & $12.96 * * *$ \\
\hline LLR-1 & 1.429 & 0.653 & $12.44 \%$ & 2.009 & 1.358 & $4742.00 \%$ & $6.28 * * *$ \\
\hline LLR-2 & 1.271 & 0.512 & $0.57 \%$ & 1.363 & 0.647 & $1130.00 \%$ & $1.81 * *$ \\
\hline LLR-3 & 1.264 & 0.499 & $-2.20 \%$ & 1.224 & 0.374 & $-124.00 \%$ & 1.03 \\
\hline LLR-4 & 1.292 & 0.514 & & 1.240 & 0.403 & & $1.32 * *$ \\
\hline LLIMP0 & 0.296 & 1.139 & $-42.46 \%$ & 0.042 & 0.080 & $-90.45 \%$ & $3.63 * * *$ \\
\hline LLIMP-1 & 0.515 & 1.589 & $-29.10 \%$ & 0.444 & 2.832 & $-23.53 \%$ & 0.36 \\
\hline LLIMP-2 & 0.726 & 2.116 & $-17.91 \%$ & 0.580 & 1.660 & $-77.64 \%$ & 0.89 \\
\hline LLIMP-3 & 0.885 & 3.124 & $-53.28 \%$ & 2.594 & 14.178 & $16.29 \%$ & $1.92 * * *$ \\
\hline LLIMP-4 & 1.894 & 4.671 & & 2.231 & 7.104 & & 0.65 \\
\hline AGR0 & 6.457 & 13.847 & $-45.11 \%$ & -1.465 & 18.665 & $-109.71 \%$ & $5.57 * * *$ \\
\hline AGR-1 & 11.762 & 23.277 & $-8.48 \%$ & 15.088 & 41.322 & $-35.65 \%$ & $1.15 *$ \\
\hline AGR-2 & 12.852 & 32.472 & $-23.23 \%$ & 23.445 & 34.852 & $-27.73 \%$ & $3.63 * * *$ \\
\hline AGR-3 & 16.740 & 61.890 & $26.91 \%$ & 32.439 & 49.044 & $-2.86 \%$ & $3.25 * * *$ \\
\hline AGR-4 & 13.190 & 28.513 & & 45.118 & 45.118 & & $9.77 * * *$ \\
\hline
\end{tabular}

The table presents the descriptive statistics, percentage change in mean values and $t$-statistics for the Asset Quality variables from Year-4 to Yearo. IMPE is the ratio of impaired loans to total equity, IMPL is the ratio of impaired loans to gross loans, LOANGROWTH is the bank's year-on-year growth in loans, LLR is the loan loss reserves, LLIMP is the ratio of loan loss reserves to impaired loans, and AGR is the bank's year-on-year asset growth rate. Full variable definitions are in Table 1. ***, $* *$, and $*$ indicate significance at the $1 \%, 5 \%$, and $10 \%$ level respectively. 
Table 4. Descriptive Statistics and $t$-test for Management Efficiency

\begin{tabular}{|c|c|c|c|c|c|c|c|}
\hline \multirow{2}{*}{$\begin{array}{c}\text { Management } \\
\text { Efficiency }\end{array}$} & \multicolumn{3}{|c|}{ Non-Failed Banks } & \multicolumn{3}{|c|}{ Failed Banks } & \multirow{2}{*}{$t$-stat } \\
\hline & Mean & Std. Dev. & \% Change & Mean & Std. Dev. & $\%$ Change & \\
\hline CIR0 & 76.530 & 36.966 & $0.81 \%$ & 147.782 & 96.926 & $66.46 \%$ & $11.22 * * *$ \\
\hline CIR-1 & 75.916 & 28.791 & $2.47 \%$ & 88.779 & 46.882 & $19.76 \%$ & $3.82 * * *$ \\
\hline CIR-2 & 74.089 & 27.039 & $2.18 \%$ & 74.131 & 38.475 & $-4.25 \%$ & 0.01 \\
\hline CIR-3 & 72.509 & 29.078 & $3.08 \%$ & 77.422 & 60.374 & $0.91 \%$ & 1.19 \\
\hline CIR-4 & 70.342 & 24.524 & & 76.721 & 70.988 & & $1.38 * *$ \\
\hline ROAA0 & 0.449 & 1.235 & $-11.84 \%$ & -4.119 & 3.347 & $623.34 \%$ & $20.92 * * *$ \\
\hline ROAA-1 & 0.509 & 1.942 & $-43.20 \%$ & -0.569 & 2.009 & $-205.16 \%$ & $6.31 * * *$ \\
\hline ROAA-2 & 0.896 & 1.983 & $-10.95 \%$ & 0.542 & 1.507 & $-32.80 \%$ & $2.32 * * *$ \\
\hline ROAA-3 & 1.006 & 1.946 & $-0.74 \%$ & 0.806 & 1.608 & $-6.75 \%$ & $1.29 * *$ \\
\hline ROAA-4 & 1.013 & 1.696 & & 0.864 & 1.731 & & 1.01 \\
\hline
\end{tabular}

The table presents the descriptive statistics, percentage change in mean values and $t$-statistics for the Management Efficiency variables from Year-4 to Yearo. CIR is the cost to income ratio and ROAA is the return on average assets. Full variable definitions are in Table $1 . * * * * *$, and $*$ indicate significance at the $1 \%, 5 \%$, and $10 \%$ level respectively.

Table 4 presents the descriptive statistics, percentage change in mean values and $t$-statistics for the Management Efficiency variables in this study from Year-4 to Yearo. The cost to income ratio (CIR) for failed banks rose drastically in the years leading to failure, doubling from about 77 to 147 in just 5 years, as compared to the CIR for non-failed banks which rose albeit at a much slower pace. In contrast, return on average assets (ROAA) for both failed and non-failed banks over 5 years. However, non-failed banks recorded negative ROAAs in Year-1 and Yearo. Statistically significant $t$-statistics for CIR and ROAA is indicative of their suitability in predicting management efficiency and subsequently, bank failure.

Table 5 presents the descriptive statistics, percentage change in mean values and $t$-statistics for the Liquidity variables in this study from $\mathrm{Year}_{-4}$ to Year $_{0}$. We can see that net loans to total assets (NETLOANS) for non-failed banks to remain relatively unchanged as opposed to failed banks who failed banks which recorded about a 7\% fall in NETLOANS in Yearo. The loan to deposit ratio (LOANDEP) for both failed and non-failed banks meanwhile fell in Year-1 and Yearo, with failed banks recording a much greater fall than non-failed banks. $t$-statistics for both variables suggest that both are good indicators of potential bank failure. 
Table 5. Descriptive Statistics and $t$-test for Liquidity

\begin{tabular}{|c|r|r|r|r|r|r|l|}
\hline \multirow{2}{*}{ Liquidity } & \multicolumn{3}{|c|}{ Non-Failed Banks } & \multicolumn{3}{|c|}{ Failed Banks } & \multirow{2}{*}{-stat } \\
\cline { 2 - 8 } & Mean & Std. Dev. & \% Change & \multicolumn{1}{|c|}{ Mean } & Std. Dev. & \% Change & \\
\hline NETLOANS0 & 62.766 & 14.411 & $-2.62 \%$ & 70.718 & 10.400 & $-6.84 \%$ & $7.31 * * *$ \\
\hline NETLOANS-1 & 64.453 & 15.845 & $-1.83 \%$ & 75.908 & 10.014 & $1.49 \%$ & $9.99 * * *$ \\
\hline NETLOANS-2 & 65.657 & 15.816 & $2.42 \%$ & 74.792 & 13.205 & $-2.07 \%$ & $7.24 * * *$ \\
\hline NETLOANS-3 & 64.103 & 16.283 & $1.57 \%$ & 76.371 & 11.761 & $4.72 \%$ & $9.98 * * *$ \\
\hline NETLOANS-4 & 63.111 & 16.585 & & 72.927 & 16.021 & & $6.96 * * *$ \\
\hline & & & & & & & \\
\hline LIQ0 & 0.009 & 0.008 & $12.50 \%$ & 0.010 & 0.007 & $42.86 \%$ & $1.59 * *$ \\
\hline LIQ-1 & 0.008 & 0.008 & $14.30 \%$ & 0.007 & 0.005 & $0.00 \%$ & $2.77 * * *$ \\
\hline LIQ-2 & 0.007 & 0.007 & $-12.50 \%$ & 0.007 & 0.009 & $-12.50 \%$ & 0.14 \\
\hline LIQ-3 & 0.008 & 0.008 & $0.00 \%$ & 0.008 & 0.009 & $-11.11 \%$ & 0.28 \\
\hline LIQ-4 & 0.008 & 0.008 & & 0.009 & 0.013 & & 0.95 \\
\hline LOANDEP0 & 79.510 & 23.250 & $-7.67 \%$ & 84.500 & 14.780 & $-11.33 \%$ & $2.97 * * *$ \\
\hline LOANDEP-1 & 86.120 & 49.100 & $-0.31 \%$ & 95.300 & 18.050 & $-3.57 \%$ & $2.87 * * *$ \\
\hline LOANDEP-2 & 86.380 & 44.190 & $4.82 \%$ & 98.830 & 28.670 & $5.19 \%$ & $3.86 * * *$ \\
\hline LOANDEP-3 & 82.410 & 25.380 & $3.30 \%$ & 93.950 & 18.340 & $2.44 \%$ & $6.02 * * *$ \\
\hline LOANDEP-4 & 79.780 & 22.470 & & 91.710 & 21.760 & & $6.23 * * *$ \\
\hline
\end{tabular}

The table presents the descriptive statistics, percentage change in mean values and $t$-statistics for the Liquidity variables from Year-4 to Yearo. NETLOANS is the ratio of net loans to total assets, LIQ is the ratio of liquid funds to total assets, and LOANDEP is loans to deposits ratio. Full variable definitions are in Table 1. ***,**, and * indicate significance at the $1 \%$, $5 \%$, and $10 \%$ level respectively.

Table 6 presents the descriptive statistics, percentage change in mean values and $t$-statistics for the Earnings and Net Interest Income variables in this study from Year -4 to Year ${ }_{0}$. Net income to average equity (ROAE) stands out in particular. We can see that in the years leading up to Yearo, both failed and non-failed banks recorded falling ROAEs. However, non-failed banks were able to maintain a positive ROAE. Failed banks in contrast, recorded a fall of more than $1,000 \%$ from Year $_{-1}$ to Yearo. Though not to this extent, a similar trend can be observed for net interest margins (NIM) for both samples; indicating that holding high-risk, high-yield assets initially increases the NIM of banks but when the bank faces financial distress, increasing funding costs and high levels of defaults deteriorate NIM. (Despagne, 2010). The magnitude of change observed for both variables is suggestive of their explanatory power. Outside the CAMEL framework, other financial items may provide indication as to the health of the bank. Non-interest income have often been perceived as riskier (Allen \& Jagtiani, 2000; Clark et al, 2007; DeYoung \& Torna, 2012) but may also be seen as a diversification of business, if carefully executed (Gamra and Plihon, 2011). Our non-failed bank sample seem to fall into the latter category, recording much higher levels of non-interest income as compared to failed banks. It is possible that a well-diversified mix of interest and non-interest sources of income lowers insolvency risks whilst improving profitability (Sanya and Wolfe, 2010). 
Table 6. Descriptive Statistics and $t$-test for Earnings \& Net Interest Income

\begin{tabular}{|c|c|c|c|c|c|c|c|}
\hline \multirow{2}{*}{$\begin{array}{l}\text { Earnings \& Net } \\
\text { Interest Income }\end{array}$} & \multicolumn{3}{|c|}{ Non-Failed Banks } & \multicolumn{3}{|c|}{ Failed Banks } & \multirow{2}{*}{$t$-stat } \\
\hline & Mean & Std. Dev. & $\%$ Change & Mean & Std. Dev. & $\%$ Change & \\
\hline ROAE0 & 3.527 & 13.422 & $-23.99 \%$ & -76.054 & 89.775 & $1017.24 \%$ & $14.33 * * *$ \\
\hline ROAE-1 & 4.640 & 13.078 & $-40.27 \%$ & -6.807 & 23.196 & $-164.05 \%$ & $7.02 * * *$ \\
\hline ROAE-2 & 7.768 & 8.124 & $-20.63 \%$ & 10.628 & 10.593 & $58.30 \%$ & $3.49 * * *$ \\
\hline ROAE-3 & 9.787 & 7.686 & $-8.26 \%$ & 6.714 & 12.306 & $-41.34 \%$ & $3.46 * * *$ \\
\hline ROAE-4 & 10.668 & 8.223 & & 11.445 & 9.656 & & 1.01 \\
\hline NIM0 & 3.951 & 1.048 & $2.28 \%$ & 2.976 & 1.183 & $-20.31 \%$ & $10.08 * * *$ \\
\hline NIM-1 & 3.863 & 1.055 & $-2.33 \%$ & 3.734 & 1.107 & $-13.54 \%$ & $1.37 * *$ \\
\hline NIM-2 & 3.955 & 1.055 & $-3.18 \%$ & 4.319 & 1.157 & $-4.07 \%$ & $3.80 * * *$ \\
\hline NIM-3 & 4.085 & 1.375 & $0.22 \%$ & 4.503 & 1.212 & $2.24 \%$ & $3.73 * * *$ \\
\hline NIM-4 & 4.076 & 1.229 & & 4.404 & 1.241 & & $3.07 * * *$ \\
\hline INTEREST0 & 14.922 & 35.863 & $-11.22 \%$ & 9.828 & 80.088 & $-17.66 \%$ & $0.94 *$ \\
\hline INTEREST-1 & 16.808 & 17.201 & $-0.54 \%$ & 11.936 & 25.600 & $-1.42 \%$ & $2.58 * * *$ \\
\hline INTEREST-2 & 16.898 & 12.844 & $-4.51 \%$ & 12.108 & 9.855 & $-9.04 \%$ & $4.84 * * *$ \\
\hline INTEREST-3 & 17.696 & 12.435 & $0.28 \%$ & 13.311 & 10.652 & $-6.02 \%$ & $4.38 * * *$ \\
\hline INTEREST-4 & 17.647 & 13.688 & & 14.164 & 11.035 & & $3.24 * * *$ \\
\hline
\end{tabular}

The table presents the descriptive statistics, percentage change in mean values and $t$-statistics for the Earnings and Net Interest Income variables from Year-4 to Yearo. ROAE is ratio of net income to average equity, NIM is ratio of net interest margin to total earning assets, and INTEREST is the ratio of non-interest fee income to total income. Full variable definitions are in Table 1. ${ }^{* *}, * *$, and $*$ indicate significance at the $1 \%, 5 \%$, and $10 \%$ level respectively.

Table 7 presents the descriptive statistics, percentage change in mean values and $t$-statistics for the Off-balance Sheet Items and Short-term Wholesale Funds variables in this study from Year${ }_{4}$ to Yearo. Off-balance sheet items (OBS) have similarly been perceived as risky as their true nature is often not made publicly known. Our sample shows both failed and non-failed banks to hold an almost equal amount of OBS. Although $t$-tests show statistically significant differences between the two in the earlier years, the magnitude seems to have fallen leading up to Yearo. A similar trend can be observed for the banks' reliance on short-term wholesale funding (WST). Although WST mean values suggest failed banks rely heavily on WST, $t$-tests do not indicate a statistically significant difference between the two samples. 
Table 7. Descriptive Statistics and $t$-test for Off-Balance Sheet Items \& Short-term Wholesale Funds

\begin{tabular}{|c|c|c|c|c|c|c|c|}
\hline \multirow{2}{*}{$\begin{array}{c}\text { Off-Balance } \\
\text { Sheet Items \& } \\
\text { Short-term } \\
\text { Wholesale Funds }\end{array}$} & \multicolumn{3}{|c|}{ Non-Failed Banks } & \multicolumn{3}{|c|}{ Failed Banks } & \multirow{2}{*}{$t$-stat } \\
\hline & Mean & Std. Dev. & $\begin{array}{c}\% \\
\text { Change }\end{array}$ & Mean & Std. Dev. & $\%$ Change & \\
\hline OBS0 & 0.015 & 0.035 & $22.71 \%$ & 0.011 & 0.023 & $-16.87 \%$ & $1.55 * *$ \\
\hline OBS-1 & 0.012 & 0.011 & $5.63 \%$ & 0.013 & 0.009 & $-23.25 \%$ & $1.15 *$ \\
\hline OBS-2 & 0.012 & 0.008 & $-3.80 \%$ & 0.017 & 0.019 & $-18.68 \%$ & $4.45 * * *$ \\
\hline OBS-3 & 0.012 & 0.008 & $-0.32 \%$ & 0.021 & 0.042 & $13.75 \%$ & $3.52 * * *$ \\
\hline OBS-4 & 0.012 & 0.008 & & 0.019 & 0.011 & & $7.86 * * *$ \\
\hline WST0 & 50.960 & 111.527 & $-45.07 \%$ & 61.991 & 137.521 & $-39.03 \%$ & $1.02 *$ \\
\hline WST-1 & 92.770 & 169.877 & $-12.97 \%$ & 101.671 & 169.800 & $-5.56 \%$ & 0.61 \\
\hline WST-2 & 106.595 & 171.197 & $39.52 \%$ & 107.657 & 182.345 & $6.11 \%$ & 0.07 \\
\hline WST-3 & 76.399 & 133.777 & $-7.24 \%$ & 101.461 & 174.821 & $-5.69 \%$ & $1.86 * *$ \\
\hline WST-4 & 82.360 & 139.420 & & 107.581 & 176.327 & & $1.83 * *$ \\
\hline
\end{tabular}

The table presents the descriptive statistics, percentage change in mean values and $t$-statistics for the Off-Balance Sheet Items and Short-term Wholesale Funds variables from Year-4 to Yearo. OBS is ratio of off-balance sheet items to total assets and WST is the ratio of volatile wholesale short-term liabilities to liquid assets. Full variable definitions are in Table $1 .{ }^{* * *}$, **, and * indicate significance at the $1 \%, 5 \%$, and $10 \%$ level respectively.

\subsection{Logistic Regression Estimation}

The discussion of the descriptive statistics above provides early insight into which variables can discriminate between failed and non-failed banks. To identify the variables that can provide early warning signals of bank distress in advance, we perform a cross-sectional logistic regression for each of the 5 years preceding bank failure. Although our $t$-tests identified a number of financial ratios that may have strong explanatory power in predicting bank failure, we only use one measure for every aspect of bank health (Espahbodi, 1991) since logit models are sensitive towards multicollinearity (Balcaen and Ooghe, 2005). The regression estimates are presented in Table 8 below. 
Table 8. Logistic Regression Estimation

\begin{tabular}{|c|c|c|c|c|c|}
\hline Explanatory Variables & Yearo & Year $-1_{1}$ & Year-2 $_{2}$ & Year $-3_{3}$ & Year-4 \\
\hline TOTCAP & $\begin{array}{l}-0.222 * * * \\
(0.081)\end{array}$ & $\begin{array}{l}-0.172 * * * \\
(0.042)\end{array}$ & $\begin{array}{l}0.012 \\
(0.013)\end{array}$ & $\begin{array}{l}-0.095^{* * *} \\
(0.031)\end{array}$ & $\begin{array}{l}-0.009 \\
(0.022)\end{array}$ \\
\hline IMPE & $\begin{array}{l}0.016^{* * *} \\
(0.004)\end{array}$ & $\begin{array}{l}0.024 * * * \\
(0.006)\end{array}$ & $\begin{array}{l}0.023 * * * \\
(0.008)\end{array}$ & $\begin{array}{l}0.016 \\
(0.016)\end{array}$ & $\begin{array}{l}0.046^{* *} \\
(0.019)\end{array}$ \\
\hline LLR & $\begin{array}{l}-0.117 \\
(0.159)\end{array}$ & $\begin{array}{l}0.245 \\
(0.174)\end{array}$ & $\begin{array}{l}0.216 \\
(0.209)\end{array}$ & $\begin{array}{l}0.384 \\
(0.276)\end{array}$ & $\begin{array}{l}0.138 \\
(0.254)\end{array}$ \\
\hline LOANGROWTH & $\begin{array}{l}0.15 \\
(0.011)\end{array}$ & $\begin{array}{l}0.013^{* * *} \\
(0.005)\end{array}$ & $\begin{array}{l}0.007 * * * \\
(0.002)\end{array}$ & $\begin{array}{l}0.003 \\
(0.002)\end{array}$ & $\begin{array}{l}0.025^{* * *} \\
(0.005)\end{array}$ \\
\hline ROAA & $\begin{array}{l}-0.661 * * * \\
(0.124)\end{array}$ & $\begin{array}{l}-0.239 * * \\
(0.116)\end{array}$ & $\begin{array}{l}-0.311 * * \\
(0.157)\end{array}$ & $\begin{array}{l}-0.192 \\
(0.198)\end{array}$ & $\begin{array}{l}-0.033 \\
(0.178)\end{array}$ \\
\hline CIR & $\begin{array}{l}0.005 \\
(0.004)\end{array}$ & $\begin{array}{l}-0.001 \\
(0.004)\end{array}$ & $\begin{array}{l}-0.006 \\
(0.005)\end{array}$ & $\begin{array}{l}0.004 \\
(0.006)\end{array}$ & $\begin{array}{l}0.004 \\
(0.004)\end{array}$ \\
\hline NIM & $\begin{array}{l}-0.108 \\
(0.196)\end{array}$ & $\begin{array}{l}0.032 \\
(0.121)\end{array}$ & $\begin{array}{l}0.445^{* * *} \\
(0.120)\end{array}$ & $\begin{array}{l}0.424 * * * \\
(0.127)\end{array}$ & $\begin{array}{l}0.287 * * \\
(0.127)\end{array}$ \\
\hline NETLOANS & $\begin{array}{l}0.029 \\
(0.018)\end{array}$ & $\begin{array}{l}0.054 * * * \\
(0.011)\end{array}$ & $\begin{array}{l}0.046^{* * *} \\
(0.009)\end{array}$ & $\begin{array}{l}0.060^{* * *} \\
(0.011)\end{array}$ & $\begin{array}{l}0.040 * * * \\
(0.010)\end{array}$ \\
\hline Constant & -1.526 & $-2.902 * *$ & $-5.359 * * *$ & $-5.631 * * *$ & $-5.170^{* * *}$ \\
\hline Log likelihood & 187.847 & 503.16 & 607.308 & 541.216 & 518.826 \\
\hline Nagelkerke R Square & 0.837 & 0.446 & 0.24 & 0.315 & 0.297 \\
\hline Prob. $>\chi^{2}$ & 0.000 & 0.000 & 0.000 & 0.000 & 0.000 \\
\hline
\end{tabular}

Variable definitions are in Table 1. Robust standard errors are in parentheses. $* * *, * *$, and $*$ indicate statistical significance at the $1 \%, 5 \%$, and $10 \%$ level respectively.

From Table 8, we can see that in the years where the coefficient estimates were significant, the coefficient signs are as argued earlier. TOTCAP and ROAA were negative i.e. higher levels of capitalization and greater management efficiency mitigates the probability of failure. NETLOANS, LOANGROWTH and IMPE meanwhile were positive as expected. Interestingly, NIM estimates suggest that higher levels of NIM in the earlier years is indicative of risky behaviour which eventually leads to failure i.e. positive coefficient sign from Year-4 to Year-1 and subsequently, negative in Yearo. LLR and CIR however, did not show any statistically significant power in predicting bank failure.

We re-estimated the logit model twice to avoid multicollinearity, each time using a different proxy to represent a particular aspect of bank health. In Model 1, we replaced NETLOANS with LOANDEP to represent liquidity while in Model 2, we used IMPL as a proxy for asset quality instead of IMPE. The estimates of Model 1 and 2 are consistent with those presented in Table 8, with both LOANDEP and IMPL showing a statistically significant positive relationship to bank failure (Note 3). From our regression estimates, we can conclude that eight financial ratios are significant predictors of bank failures: TOTCAP, IMPE, LOANGROWTH, 
ROAA, NIM, NETLOANS, LOANDEP; and IMPL.

The classification accuracy of the model for the year of failure and the four years preceding it are illustrated in the Table 9 below.

Table 9. Classification Accuracy

\begin{tabular}{|l|c|c|c|c|c|}
\hline \multicolumn{7}{|c|}{ Panel A: In-Sample } \\
\hline & Year 0 & Year-1 & Year-2 & Year-3 & Year-4 \\
\hline Overall classification accuracy & $91.82 \%$ & $71.81 \%$ & $72.41 \%$ & $73.40 \%$ & $73.20 \%$ \\
\hline Correct classification of failed banks & $89.86 \%$ & $81.30 \%$ & $73.73 \%$ & $76.92 \%$ & $66.36 \%$ \\
\hline Correct classification of non-failed banks & $93.46 \%$ & $78.29 \%$ & $71.09 \%$ & $70.12 \%$ & $79.18 \%$ \\
\hline Type I error & $10.14 \%$ & $18.70 \%$ & $26.27 \%$ & $23.08 \%$ & $33.64 \%$ \\
\hline Type II error & $6.54 \%$ & $21.71 \%$ & $28.91 \%$ & $29.88 \%$ & $20.82 \%$ \\
\hline
\end{tabular}

\begin{tabular}{|l|c|c|c|c|c|}
\hline \multicolumn{5}{|c|}{ Panel B: Out-of-Sample } \\
\hline & Year 0 & Year-1 & Year-2 & Year-3 & Year-4 \\
\hline Overall accuracy & $96.15 \%$ & $87.69 \%$ & $76.15 \%$ & $81.54 \%$ & $72.31 \%$ \\
\hline Correct classification of failed banks & $100 \%$ & $95.38 \%$ & $89.23 \%$ & $96.92 \%$ & $84.62 \%$ \\
\hline Correct classification of non-failed banks & $92.31 \%$ & $80.00 \%$ & $63.08 \%$ & $66.15 \%$ & $60.00 \%$ \\
\hline Type I error & $0 \%$ & $4.62 \%$ & $10.77 \%$ & $3.02 \%$ & $15.38 \%$ \\
\hline Type II error & $7.69 \%$ & $20 \%$ & $36.92 \%$ & $33.85 \%$ & $40.00 \%$ \\
\hline
\end{tabular}

In-sample tests (Panel A, Table 9) show that the model displays fairly reasonable predictive power considering past studies have suggested that failure-prediction models are only reliable up until two years before failure (Altman, 2000; Espahbodi, 1991; Meyer \& Pifer, 1970). Overall, our model is about $70 \%$ accurate, increasing to $91.82 \%$ in Year 0 . Our model also seems to be more accurate in predicting failure even up to as far as Year-1. It is however expected that accuracy of correct classification will fall the further away it is from Yearo. We have also managed to keep Type I errors i.e. the probability of incorrectly classifying a failed bank as non-failed, lower than Type II errors i.e. the probability of incorrectly classifying non-failed banks as failed, in the years preceding failure. As misclassification costs arising from Type I error are greater (Barr and Siems, 1997; Fidrmuc and Sub; 2011), relatively lower Type I errors in our model suggests greater predictive power. Although the model has high in-sample accuracy, we conduct further tests to evaluate its reliability and validity in classifying out of sample data (Jones, 1987). The out-of-sample predictive accuracy was tested using a sample of U.S. commercial banks from 2011. The hold out sample consists of 65 failed banks in year 2011, matched by a sample of 65 non-failed banks according to asset size in the same year. The results presented in Panel B, Table 9 show that our model has a high overall rate of accuracy even up to Year-1 with minimal Type I error. Accuracy of correctly classifying a failed bank is near perfect in Year-1 and perfect in Yearo. Type I errors were well below Type II errors and are also much lower than what was observed in the in-sample test. The accuracy of our model is greater than that of Glezakos et al. (2010) i.e. ours is able to predict failure at a higher degree 
of accuracy $(100 \%-85 \%)$ as compared to theirs $(60 \%-55 \%)$. We must note however that the accuracy of our model in correctly classifying healthy banks is similar to theirs.

\subsection{The Soundness of Malaysian Banks}

Having identified the financial variables that are able to effectively distinguish between healthy and unhealthy banks, we then construct 'value ranges' to assess the soundness of Malaysian commercial banks by computing $95 \%$ confidence intervals around the mean values of each variable for both the failed and non-failed sample banks. Since the predictive power of the variables diminish beyond two years prior to failure, we only computed value ranges for Year$I$ and Year $_{-2}$, although a few variables were only significant for just one year. The value ranges are presented in Table 10 below.

Table 10. Value Ranges of Bank Distress Indicators

\begin{tabular}{|c|c|c|c|c|}
\hline & \multicolumn{2}{|c|}{ Non-failed (\%) } & \multicolumn{2}{|c|}{ Failed (\%) } \\
\hline & Lower boundary & Upper boundary & Lower boundary & Upper boundary \\
\hline TOTCAP $_{-1}$ & 15.73 & 19.78 & 11.35 & 12.11 \\
\hline TOTCAP $_{-2}$ & \multicolumn{2}{|c|}{$\mathbf{N} / \mathbf{S}$} & \multicolumn{2}{|c|}{$\mathbf{N} / \mathbf{S}$} \\
\hline NETLOANS $_{-1}$ & 62.53 & 66.73 & 74.70 & 77.11 \\
\hline NETLOANS $_{-2}$ & 63.73 & 67.58 & 73.17 & 76.41 \\
\hline LOANGROWTH $_{-1}$ & \multicolumn{2}{|c|}{$\mathbf{N} / \mathbf{S}$} & \multicolumn{2}{|c|}{$\mathbf{N} / \mathbf{S}$} \\
\hline LOANGROWHT $_{-2}$ & 11.67 & 24.29 & 24.33 & 41.74 \\
\hline ROAA-1 $_{-1}$ & 0.2739 & 0.7437 & -0.81 & -0.33 \\
\hline $\mathrm{ROAA}_{-2}$ & \multicolumn{2}{|c|}{$\mathbf{N} / \mathbf{S}$} & \multicolumn{2}{|c|}{$\mathbf{N} / \mathbf{S}$} \\
\hline $\mathrm{NIM}_{-1}$ & \multicolumn{2}{|c|}{$\mathbf{N} / \mathbf{S}$} & \multicolumn{2}{|c|}{$\mathbf{N} / \mathbf{S}$} \\
\hline $\mathrm{NIM}_{-2}$ & 3.83 & 4.08 & 4.18 & 4.46 \\
\hline IMPE-1 & 10.55 & 15.93 & 45.74 & 62.24 \\
\hline $\mathrm{IMPE}_{-2}$ & 5.32 & 8.52 & 11.22 & 15.91 \\
\hline LOANDEP $_{-1}$ & 80.15 & 92.08 & 93.13 & 97.47 \\
\hline LOANDEP-2 $_{-2}$ & 80.99 & 91.78 & 95.36 & 102.29 \\
\hline IMPL-1 $_{-1}$ & 1.74 & 2.52 & 4.62 & 5.94 \\
\hline IMPL-2 $_{-2}$ & 1.13 & 1.63 & 1.33 & 1.87 \\
\hline
\end{tabular}

Note: N/S indicates non-statistically significant coefficient estimate

We then categorise the value ranges in Table 10 into five distinct tranches, colour-coded for ease of presentation: (1) critical i.e. recorded ratio is worse than failed banks (in red); (2) unsound i.e. ratio is within failed banks' range (in pink); (3) moderate i.e. ratio is between failed and non-failed range (in yellow); (4) sound i.e. ratio is within non-failed range (in light green); and (5) excellent i.e. ratio is better than non-failed banks (in dark green). Interpretation of the value ranges is variable-specific. For variables negatively related to the likelihood of failure, higher ratios indicate better health. Ratios falling below the 'failed' range will thus be considered 'critical' while ratios above 'non-failed' are considered 'excellent'. For variables 


\section{Macrothink}

Asian Journal of Finance \& Accounting

ISSN 1946-052X 2019, Vol. 11, No. 1

positively related to bank failure, ratios above the 'failed' range are considered 'critical' while ratios below 'non-failed' are considered 'excellent'. Interpreting LOANGROWTH however, requires more discretion as too low a value may indicate inability in generating profits while too high a value may indicate poor lending practices.

We assessed the soundness of 20 domestic and foreign commercial banks in Malaysia as of 2011 based on our colour-coded categories above. The results of the assessment are presented in Table 11 below.

Table 11. Malaysian commercial bank soundness assessment

\begin{tabular}{|c|c|c|c|c|c|c|c|c|}
\hline Bank & 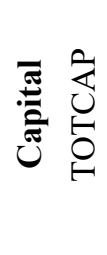 & 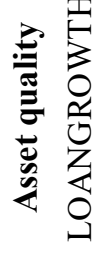 & 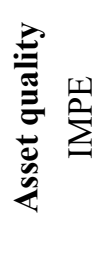 & 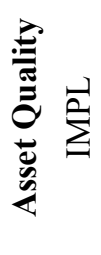 & 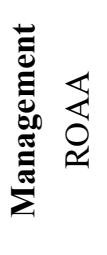 & 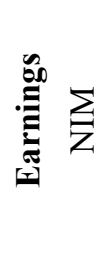 & 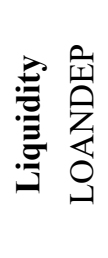 & 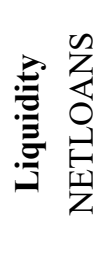 \\
\hline \multicolumn{9}{|l|}{ Affin } \\
\hline \multicolumn{9}{|l|}{ AmBank } \\
\hline \multicolumn{9}{|l|}{ Alliance } \\
\hline \multicolumn{9}{|l|}{ Bangkok } \\
\hline \multicolumn{9}{|l|}{ Bank of America } \\
\hline \multicolumn{9}{|l|}{ Bank of Nova Scotia } \\
\hline \multicolumn{9}{|c|}{ Bank of Tokyo Mitsubishi } \\
\hline \multicolumn{9}{|l|}{ CIMB } \\
\hline \multicolumn{9}{|l|}{ Citibank } \\
\hline \multicolumn{9}{|l|}{ Deutsche } \\
\hline \multicolumn{9}{|l|}{ Hong Leong } \\
\hline \multicolumn{9}{|l|}{ HSBC } \\
\hline \multicolumn{9}{|l|}{ JP Morgan Chase } \\
\hline \multicolumn{9}{|l|}{ Maybank } \\
\hline \multicolumn{9}{|l|}{$\mathrm{OCBC}$} \\
\hline \multicolumn{9}{|l|}{ Public Bank } \\
\hline \multicolumn{9}{|l|}{ RHB } \\
\hline \multicolumn{9}{|l|}{ Royal Bank of Scotland } \\
\hline \multicolumn{9}{|l|}{ Standard Chartered } \\
\hline United Overseas Bank & & & & & & & & \\
\hline
\end{tabular}

The soundness of Malaysian commercial banks is assessed on 8 categories formed on the basis of the value ranges in Table 10. Each category is divided into 5 tranches: Critical (in red); Unsound (in pink); Moderate (in yellow); Sound (in light green); and Excellent (in dark green).

The bank soundness assessment in Table 11 shows that for the most part, Malaysian commercial banks seem to be reasonably sound. A few problem areas exist however, especially in terms of capitalisation and asset quality. We can see that banks such as AmBank, Alliance, 


\section{Macrothink}

Bank of America, Bank of Tokyo and Citibank have very low or even negative loan growth rates $(-12.63 \% ; 4.92 \% ;-36.86 \% ; 6.51 \%$ and $4.29 \%$ respectively), while United Overseas Bank recorded exceptionally high loan growth rates (35.4\%). Other aspects of asset quality seem to be acceptable with the exception of Royal Bank of Scotland which recorded a high amount of IMPL (11.65\%). Earnings wise, Bank of America recorded high levels of NIM (8.18\%) while Citibank was just the opposite (4.26\%). With regards to liquidity, we can see that both AmBank and Bangkok Bank recorded high levels of LOANDEP (96.79 and 97.82 respectively) while the Bank of Nova Scotia is seemingly facing liquidity problems with high levels of LOANDEP and NETLOANS ( $>200 \%$ ). The above assessment shows that $35 \%$ ( 7 out of 20 banks) of the commercial banks in Malaysia have asset quality issues, 20\% (4 banks) have problem liquidity issues and 10\% ( 2 banks) have problems with earnings.

\subsection{Constructing the Bank Soundness Index}

Although the construction of a soundness assessment framework for banks has provided us some insight to the bank's health, there is still a need for assessments from a wider perspective that allows for inter-bank comparisons to be made. We thus construct a 'Bank Health Index' that gives regulators and interested parties a birds-eye view of the soundness of the overall banking industry in the country. The Bank Health Index is computed on a score ranging from 0 to 10 for each component - capital; asset quality; management efficiency; earnings; and liquidity - its summation an overall "health score" for the individual bank. With each bank's health score, an industry score can be computed, allowing for comparisons against the overall banking system to be made. The health scores for each bank are presented in Table 12 below. 


\section{Macrothink}

Asian Journal of Finance \& Accounting

ISSN 1946-052X

2019, Vol. 11, No. 1

Table 12. Bank Health Index Scores

\begin{tabular}{|c|c|c|c|c|c|c|c|c|c|c|c|}
\hline & & Ownership & Capialization & $\begin{array}{c}\text { Management } \\
\text { Efficiency }\end{array}$ & $\begin{array}{c}\text { Asset } \\
\text { Quality }\end{array}$ & Earnings & Liquidity & Total Score & Health Score & Total Assets & $\begin{array}{c}\text { Weighted } \\
\text { Score }\end{array}$ \\
\hline 1 & $\begin{array}{l}\text { Bank of } \\
\text { Tokyo- } \\
\text { Mitsubishi }\end{array}$ & $\mathrm{F}$ & 9.25 & 8.06 & 8.54 & 7.57 & 10 & 43.42 & 86.85 & 2919 & 0.46 \\
\hline 2 & $\begin{array}{l}\text { JP Morgan } \\
\text { Chase }\end{array}$ & F & 10 & 7.06 & 7.19 & 6.61 & 10 & 40.86 & 81.73 & 2366 & 0.35 \\
\hline 3 & $\begin{array}{l}\text { Royal Bank } \\
\text { of Scotland }\end{array}$ & $\mathrm{F}$ & 6.07 & 6.19 & 5.46 & 9.56 & 10 & 37.29 & 74.57 & 1434 & 0.2 \\
\hline 4 & HSBC & F & 5.25 & 8.26 & 6.27 & 7.06 & 10 & 36.84 & 73.68 & 25094 & 3.37 \\
\hline 5 & $\begin{array}{l}\text { Standard } \\
\text { Chartered }\end{array}$ & $\mathrm{F}$ & 5.23 & 7.82 & 6.9 & 7.5 & 8.69 & 36.13 & 72.26 & 15531 & 2.05 \\
\hline 6 & $\begin{array}{l}\text { Deutsche } \\
\text { Bank }\end{array}$ & F & 5.63 & 5.22 & 8.23 & 6.95 & 10 & 36.03 & 72.06 & 3727 & 0.49 \\
\hline 7 & CIMB & $\mathrm{L}$ & 6.61 & 7.58 & 5.92 & 6.16 & 9.05 & 35.33 & 70.65 & 73783 & 9.51 \\
\hline 8 & Public Bank & $\mathrm{L}$ & 6.21 & 8.38 & 7.86 & 6.23 & 6.19 & 34.86 & 69.71 & 78505 & 9.98 \\
\hline 9 & $\begin{array}{l}\text { Hong } \\
\text { Leong }\end{array}$ & $\mathrm{L}$ & 5.44 & 6.83 & 5.61 & 6.98 & 10 & 34.85 & 69.71 & 49471 & 6.29 \\
\hline 10 & $\begin{array}{l}\text { Bangkok } \\
\text { Bank }\end{array}$ & F & 9.93 & 5.5 & 6.88 & 7.07 & 4.87 & 34.25 & 68.5 & 852 & 0.11 \\
\hline 11 & $\begin{array}{l}\text { Alliance } \\
\text { Bank }\end{array}$ & $\mathrm{L}$ & 6.48 & 7.59 & 4.36 & 6.24 & 9.55 & 34.22 & 68.43 & 12898 & 1.61 \\
\hline 12 & OCBC & $\mathrm{F}$ & 6.23 & 7.65 & 5.28 & 6.76 & 7.08 & 32.99 & 65.98 & 20271 & 2.44 \\
\hline 13 & Citibank & $\mathrm{F}$ & 5.97 & 9 & 4.89 & 3.03 & 10 & 32.88 & 65.76 & 13991 & 1.68 \\
\hline 14 & $\begin{array}{l}\text { Bank of } \\
\text { Nova Scotia }\end{array}$ & $\mathrm{F}$ & 8.59 & 8.77 & 6.71 & 6.68 & 2.08 & 32.82 & 65.65 & 1560 & 0.19 \\
\hline 15 & $\begin{array}{l}\text { Bank of } \\
\text { America }\end{array}$ & $\mathrm{F}$ & 10 & 6.51 & 6.22 & 0 & 10 & 32.73 & 65.46 & 491 & 0.06 \\
\hline 16 & RHB & $\mathrm{L}$ & 6.33 & 7.46 & 5.26 & 6.12 & 7.24 & 32.42 & 64.83 & 45006 & 5.32 \\
\hline 17 & Affin & $\mathrm{L}$ & 4.66 & 6.76 & 5.84 & 6.28 & 8.78 & 32.32 & 64.64 & 15501 & 1.83 \\
\hline 18 & $\begin{array}{l}\text { Maybank } \\
\text { United }\end{array}$ & $\mathrm{L}$ & 6.02 & 7.61 & 4.72 & 6.52 & 7.01 & 31.87 & 63.75 & 136388 & 15.86 \\
\hline 19 & $\begin{array}{l}\text { Overseas } \\
\text { Bank }\end{array}$ & $\mathrm{F}$ & 5.9 & 7.81 & 3.87 & 6.39 & 6.3 & 30.27 & 60.53 & 21648 & 2.39 \\
\hline 20 & AmBank & $\mathrm{L}$ & 5.62 & 7.61 & 2.12 & 5.78 & 4.52 & 25.65 & 51.3 & 26896 & 2.52 \\
\hline & \multicolumn{2}{|c|}{ Industry Component Score } & 6.77 & 7.38 & 5.91 & 6.27 & 8.07 & \multicolumn{3}{|c|}{ Industry Health Score } & 66.69 \\
\hline
\end{tabular}

Note: F denotes foreign bank; L denotes domestic bank. Health score is each bank's total score indexed to100. Weighted score is the health score multiplied by the bank's total assets divided by the total assets in the entire banking industry. Industry Health Score is the summation of the weighted health scores for each bank. Scores of 100 indicate excellent health, 0 otherwise.

Table 12 presents the health scores for the 20 foreign and domestic commercial banks in 


\section{Al Macrothink}

Asian Journal of Finance \& Accounting

ISSN 1946-052X

2019, Vol. 11, No. 1

Malaysia for the year 2011. We can see that the top 3 banks in Malaysia in terms of health are Bank of Tokyo-Mitsubishi, JP Morgan Chase and the Royal Bank of Scotland while the bottom 3 are Maybank, United Overseas Bank and AmBank. We can also see that on average, banks in Malaysia are in a sound position in terms of liquidity and management efficiency but still have a long way to go in terms of capitalisation, asset quality and earnings. Eight banks had a perfect liquidity score while three had liquidity scores below 5. In terms of management efficiency, only seven banks scored below the industry average although all 20 banks scored above 5 - an acceptable level but could still be further improved. Only 2 banks had a perfect capitalisation score while only one bank scored below 5. Although most banks had capitalisation scores above 5 , some caution must be noted as only five banks recorded scores that were significantly greater than 5 . The other 14 banks only managed scores no greater than 6.7. With regards to earnings, only two banks scored below 5 . The other 18 banks recorded earnings scores that were comparable to one another and the industry average with the exception of the Royal Bank of Scotland which scored the highest (9.56). The asset quality of commercial banks in Malaysia warrants the most attention. Ten banks recorded asset quality scores below the industry average while five banks scored below 5, placing them in the critical category.

As a whole, it is reasonable to say that the Malaysian banking industry is in a state of moderate health, with a health score of $66.69-\mathrm{a} \mathrm{C}$ or $\mathrm{C}+$ at best. As a result, precautionary measures should be put in place to address these concerns, the first being the asset quality of Malaysian banks since $55.61 \%$ of the total loans in the banking sector are driven by household borrowings (BNM, 2011) where $26 \%$ of it is for residential mortgages. Banks are essentially exposing themselves to high level of concentration risk in sectors that might not be as stable as once thought. The drop in property prices as a result of the AFC and the crash in the property and mortgage market as a result of the sub-prime crisis are two prime examples of the dangers inherent in the property sector.

\section{Conclusion}

Over the last decade, we have witnessed major financial institutions collapse due to poor lending practices. Given their importance in the economy, bank failures send shockwaves across the country and the region as well - something that economies recovering from the recession can scarcely afford. Burdened with the task of steering the economy into recovery, regulators find it difficult to dedicate more resources into overseeing bank practices. Consequently, regulators need a bank health framework that makes their oversight task simpler, yet effective. Our model meets this purpose with a much higher degree of accuracy as compared to others. We also develop a Bank Health Index that allows for time-progressive monitoring of bank health, as opposed to the conventional point-in-time assessments. Progressive monitoring provides regulators with timely information allowing them to take precautionary measures in advance whenever any bank breaches a pre-determined lower threshold. The Bank Health Index also serves observers, investors and potential clients by providing information on the bank's soundness vis-à-vis other banks, allowing them to make a more informed when choosing their bank, besides keeping banks in check. 


\section{Acknowledgement}

This paper is in memory of our mentor and friend Associate Professor Balachandher Krishnan Guru, who unfortunately passed away before this paper could be published. Without his drive and guidance, this paper would have never seen the light of day.

\section{Notes}

Note 1 . In the t-test, the hypothesis is stated as follows: $\mathrm{H}_{0}$ : the difference between the two group means is zero, $\mathrm{H}_{1}$ : the difference between the two group means is significantly different from zero.

Note 2. In this study, the failure-prediction model is not to predict failure per se, but to identify which variables have the power to predict failure in advance. It is thus necessary that the variables in the model here do show a statistically significant difference between the two samples. In previous studies of bank failure prediction, this had not been a strict requirement (Espahbodi, 1991).

Note 3. Due to space constraints, we did not report these figures here. They are however, available from us upon request.

\section{References}

Agarwal, V., \& Taffler, R. (2008). Comparing the performance of market-based and accounting-based bankruptcy prediction models. Journal of Banking and Finance, 32, 15411551, https://doi.org/10.1016/j.jbankfin.2007.07.014.

Allen, L., \& Jagtiani, J. (2000). Risk Effects of Combining Banking, Securities, and Insurance Activities. Journal of Economics and Business, 52(6), 485-497. https://doi.org/10.1016/S01486195(00)00033-3

Allen, N.B., \& Yong, R.D. (1997). Problem loan identification and cost efficiency in commercial banks. Journal of Banking and Finance, 21, 849-869.

Altman. E.I. (1968). Financial ratios, discriminant analysis and the prediction of corporate bankruptcy. The Journal of Finance, 23(4), 589-609. https://doi.org/10.2307/2978933.

Andersen, H. (2008). Failure prediction of Norwegian banks: A logit approach. Norges Bank Working paper, ANO 2008/2.Oslo.

Anginer, D., \& Demirguc-Kunt, A. (2011). Has the global banking system become more fragile over time?. Policy Research Working Paper 5849. World Bank, Washington, DC.

Anglomkliew, S., George, J., \& Packer, F. (2009). Issues and developments in loan loss provisioning: the case of Asia. Bank of International Settlements Quarterly Review 2009.

Arias, A.F. (2000). The Colombian banking crisis: Macroeconomic consequences and what to expect- Banco de la Republica and University of California at Los Angeles.

Atiya, A.F. (2001). Bankruptcy prediction for credit risk using neural networks: a survey and new results. IEEE transactions on neural networks, 12(4), 929- 935, https://doi.org/ 
https://doi.org/10.1109/72.935101.

Aziz, M. A., \& Humayon A. Dar. (2006). Predicting Corporate Bankruptcy: Where We Stand? Corporate Governance: The International Journal of Effective Board Performance, 6(1), 1833, https://doi.org/10.1108/14720700610649436.

Balcaen, S., \& Ooghe, H. (2005). 35 years of studies on business failure: an overview of the classic statistical methodologies and their related problems. The British Accounting Review, 38 (2006), 63-93, https://doi.org/10.1016/j.bar.2005.09.001.

Bank Negara Malaysia. (2011). Economic and financial developments in Malaysia in the fourth quarter 2011. Retrieved from http://www.bnm.gov.my.

Bank of International Settlements. (2004). Bank failures in mature economies. Basel Committee on Banking Supervision Working paper No.13. Retrieved from http://www.bis.org.

Barr, S.R., \& Siems, F.T. (1997). Bank failure prediction using DEA to measure management quality. In Barr, R.S, Helgason, R.V. \& Kennington, J.L. (eds.), Advances in Metaheuristics, Optimization and Stochastic Modeling techniques. Dordrecht, Kluwer, 341-365.

Beaver, W. H. (1966). Financial Ratios as Predictor of Failure. Empirical Research in Accounting: Selected Studies, 1966, supplement to the Journal of Accounting Research, (Autumn, 1966), 91-101, https://doi.org/10.2307/2490171

Bell, J., \& Pain, D. (2000). Leading indicator models of banking crises- a critical review. Bank of England.

Beltratti, A., \& Stulz, R.M. (2010). The credit crisis around the globe: why did some banks perform better? Working paper. Ohio State University.

Berg, S.A., \& Hexeberg, B. (1994). Early warning indicators for Norwegian banks: a logit analysis of the experiences from the banking crisis. Norges Bank Working Paper, No.1.

Berger, A.N., Davies, S.M., \& Flannery, M.J. (2000). Comparing market and supervisory assessments of bank performance: Who knows what when? Journal of Money, Credit and Banking, 32 (3), 641-667, https://doi.org./10.2307/2601200

Black, F., \& Scholes, M. (1973). The pricing of options and corporate liabilities. The Journal of Political Economy, 81 (3), 637-654, https://www.jstor.org/stable/1831029

Bongini, P., Laeven, L., \& Majnoni, G. (2002). How good is the market at assessing bank fragility? A horse race between different indicators. Journal of Banking \& Finance, 26 (2002), 1011-1028, https://doi.org/10.1016/S0378-4266(01)00264-3

Brossard, O., Ducrozet, F., \& Roche, A. ( 2007). An early warning model for EU banks with detection of the adverse selection effect. Cahiers du GRES 2007-08, Groupement de Recherches Economiques et Sociales.

Brunnermeier, M.K. (2009). Deciphering the Liquidity and Credit Crunch 2007-2008. Journal of Economic Perspective, 23(1), 77-100, https://doi.org/10.1257/jep.23.1.77 


\section{Macrothink}

Asian Journal of Finance \& Accounting

ISSN 1946-052X

2019, Vol. 11, No. 1

Bystrom, H.N.E. (2004). The market's view on the probability of banking sector failure: cross country comparisons. Journal of international financial markets, institutions \& money, 14(2004), 419- 438, https://doi.org/10.1016/j.intfin.2003.12.003

Canabas, S., Cabuk, A., \& Kilic, S. B. (2005). Prediction of commercial bank failure via multivariate statistical analysis of financial structures: The Turkish case. European Journal of Operational Research, 166(2), 528- 546, https://doi.org/10.1016/j.ejor.2004.03.023.

Caprio, G., \& Klingebiel, D. Bank insolvency: bad luck, bad policy or bad banking. Annual World Bank Conference on Development Economics.

Cerutti, E., Claessens, S., \& McGuire, P. (2012). Systemic risks in global banking: what can available data tell us and what more data are needed?. Bank for International Settlements Working Paper no. 376.

Ciolli, J. (2012, June 22). Euro tumbles as Moody's downgrades ratings for 15 banks. Bloomberg. Retrieved from http://www.bloomberg.com.

Clark, T., Dick, A., Hirtle, B., Stiroh, K.J., \& Williams, R. (2007). The role of banking in the US banking industry: risk, return and industry structure. Econ. Pol. Rev., Fed. Reserve Bank New York 13, 39-56.

Cleary, S., \& Hebb, G. (2010). Bankruptcy prediction for U.S. banks. NFA papers no.51. Northern Finance Association.

Cole, R.A., \& Gunther, J.W. (1995). Separating the likelihood and timing of bank failure. Journal of Banking and Finance, 19 (1995), 1073-1089, https://doi.org/10.1016/03784266(95)98952-M.

Cole, R.A. \& Wu, Q. (2009). Predicting bank failures using a simple dynamic hazard model. Retrieved from http://www.fdic.gov.

Cramer, J.S. (1991). An introduction, the logit model for economists. New York: Edward Arnold, London.

Creane, S., Goyal, R., Mubarak, M., \& Sab, R. (2004). Financial sector development in the Middle East and North Africa. IMF working paper, Washington D.C, Middle East and Central Asia Department.

Curry, T.J., Elmer, P.J., \& Fissel, G.S (2007). Equity market data, bank failure and market efficiency. Journal of Economics and Business, 6, 536-559, https://doi.org/10.1016/j.jeconbus.2007.02.002

Davis, E. P., \& Karim, D. (2008). Comparing early warning systems for banking crises. Journal of Financial Stability, 4 (2),89-120, https://doi.org/10.1016/j.jfs.2007.12.004

Demirguc-Kunt, A. \& Detragiache, E. (1997). Financial liberalization and financial fragility. International Monetary Fund Working Paper, Wp/98/83.

Demirguc-Kunt, A., \& Levine, R. (1996). Stock market development and financial 
intermediaries: stylized facts. Policy Research Working paper series 1686, The World Bank.

Demyanyk, Y. \& Hasan, I. (2010). Financial crises and bank failures: a review of prediction methods. Omega, 8 (5), 315- 324, https://doi.org/10.1016/j.omega.2009.09.007

Despagne, G. (2010). The determinants of US regional bank failures during the subprime crisis. HEC Paris. Masters thesis.

De Young, R., \& Torna, G. (2012). Non traditional banking activities and bank failures during the financial crisis. Social Science Research Network.

Diamond, D.W., \& Dybvig, P.H. (1986). Banking theory, deposit insurance, and bank regulation. Journal of Business, 59(1), 55-68, https://www.jstor.org/stable/2352687.

Dimitras, A.I., Zanakis, S.H., \& Zopounidis, C. (1996). A survey of business failures with an emphasis on prediction methods and industrial applications. European Journal of Operational Research, 90 (1996), 487- 513, https://doi.org/10.1016/0377-2217(95)00070-4.

Distinguin, I., Tarazi, A., \& Trinidad, J. (2011). The use of accounting and stock market data to predict bank financial distress: The case of East Asian banks. Philippine Management Review (Special issue), 18(2011), 1-18.

Eichengreen, B., \& Arteta, C. (2000). Banking crises in emerging markets: presumptions and evidence. Centre for International Development Economics Research (CIDER) Working paper C00-115. University of California.

Espahbodi, P. (1991). Identification of problem banks and binary choice models. Journal of Banking and Finance, 15 (1991), 53-71, https://doi.org/10.1016/0378-4266(91)90037-M.

Estrella, A., Park, S., \& Peristiani, S. (2000). Capital ratios as predictors of bank failure. FRBNY Economic Policy Review, July 2000, 6(2), 33-52.

Evanoff, D.D., \& Wall, L.D. (2001). Measures of the riskiness of banking organizations: subordinated debt-yields, risk-based capital and examination ratings. Federal Reserve Bank of Atlanta Working paper 2001-25.

Evans, O., Leone, A.M., Gill, M., \& Hilbers, P. (2000). Macroprudential indicators of financial system soundness. International monetary fund. Washington DC.

Field, A. (2005). Discovering statistics using SPSS (2 ${ }^{\text {nd }}$ ed.) London: SAGE Publications.

Firdmuc, J., \& Sü $\beta$, P.J. (2009). The outbreak of the Russian Banking Crisis: What a surprise. Munich Discussion Paper No. 2009-16.

Floro. (2010). Loan loss provisioning and the business cycle: does capital matter? Evidence from Philippine banks. Bank of International Settlements. Retrieved from http://www.bis.org.

Foos, D., Norden, L., Weber, M., (2010), Loan Growth and Riskiness of Banks, Journal of Banking and Finance, 34, 2929-2940, https://doi.org/10.1016/j.jbankfin.2010.06.007

Gamra, S.B., \& Plihon, D. (2011). Revenue diversification in emerging market banks: 
implications for financial performance. Quantitative Finance Papers, https://arxiv.org/abs/1107.0170v1

Gasbarro, D., Sadguna, I.G.M., \& Zumwalt, J.K (2002). The changing relationship between CAMEL ratings and bank soundness during the Indonesian banking crisis. Review of quantitative finance and accounting, 19 (2002), 247-260, https://doi.org/10.1023/A:1020724907031

Gaytan, A., \& Johnson, C.A. (2002). A Review of the Literature on Early Warning Systems for banking crises. Central Bank of Chile, Working paper number 183.

Gersl, A., \& Hermanek, J. (2006). Financial stability indicators: advantage and disadvantages of their use in the assessment of financial system stability. CNB financial stability report 2006. Czech National Bank, Research department.

Ghosh, J. (2005). The economic and social effects of financial liberalization: a primer for developing countries. DESA Working paper no.4.

Glezakos, M., Mylonakis, J., \& Oikonomou, K. (2010). An Empirical Research On Early Bankruptcy Forecasting Models: Does Logit Analysis Enhance Business failure predictability? European Journal of Finance and Banking Research, 3(3), 1-15.

Gonzalez-Hermosillo, B. (1999). Determinants of Ex-Ante banking system distress: A macromicro empirical exploration of some recent episodes. International Monetary Fund Working Paper, WP/99/33.

Gonzalez-Paramo, J.M. (2011). Risk, return, resilience: The future financial system. Presented at the $3^{\text {rd }} \quad$ Annual Risk and Return Russian Conference, Moscow.

Gross, R., Vesala, J., \& Vulpes, G. (2004). Market indicators, bank fragility, and indirect market discipline. Federal Reserve Bank of New York Economic Policy Review.

Gropp, R., Vesala, J., \& Vulpes, G. (2006). Equity and bond market signals as leading indicators of bank fragility. Journal of Money, Credit and Banking, 38 (2), 399- 428, https://www.jstor.org/stable/3839126

Gujarati, D.N. (1995). Basic Econometrics (3 ${ }^{\text {rd }}$ ed.). New York: McGraw-Hill.

Hanschel, E., \& Monnin, P. (2005). Measuring and forecasting stress in the banking sector: evidence from Switzerland. The Bank of International Settlements paper 22. Retrieved from http://www.bis.org.

Hanosek, J., Kocenda, E., \& Ondko, P. (2007). The banking sector in new EU member countries: a sectoral financial flows analysis, Czech Journal of Economics and Finance, 57 (5-6), 200224.

Hoggarth, G. \& Reis,R., \& Saporta,V. (2002). Costs of banking system instability: Some empirical evidence. Journal of Banking \& Finance, 26(5), 825-855, https://doi.org/10.1016/S0378-4266(01)00268-0 
Illing, M., \& Ying, L. (2003). An Index of Financial Stress for Canada. Working Papers 03-14, Bank of Canada.

International Monetary Fund. (2011). Global financial stability report. Retrieved from www.imf.org.

Jagtiani, J.A., Kolari, J.W. \& Lemieux, C.M., \& Shin, G.H. (2000). Predicting inadequate capitalization: Early warning system for banking supervision. Federal Reserve Bank of Chicago, Emerging Issues Series.

Jimenez, Gabriel and Jesus Saurina. (2005). Credit cycles, credit risk and prudential regulation. Banco De Espana Working Paper 531.

Jin, J.Y., Kanagaretnam, K., \& Lobo, G.J. (2011). Ability of accounting and audit quality variables to predict bank failure during the financial crisis. Journal of Banking \& Finance, 35 (2011), 2811-2819, https://doi.org/10.1016/j.jbankfin.2011.03.005.

Jordan, D.J., Douglas, R., Sanchez, J. Walker, C., \& Wort, D.H. (2010). Predicting bank failures: Evidence from 2007 to 2010. SSRN Working Paper.

Karacabey, A.A. (2007). Bank failure prediction using modified minimum deviation method. International Research Journal of Finance and Economics, 12 (2007), 147-159.

Karim, M.Z.A., Chan, S.G., \& Hassan, S. (2010). Bank efficiency and non-performing loans: evidence from Malaysia and Singapore. Prague Economic Papers. Retrieved from http://www.vse.cz.

Kaufman, G.G. (2009). Bank failures, systemic risk and bank regulation. CATO Journal, 16(1), 17-29.

Keasey, K., \& Watson, R. (1991). Financial distress prediction models: a review of their usefulness. British Journal of Management, 2, 89-102, https://doi.org/10.1111/j.14678551.1991.tb00019.x

King, R.G., \& Levine, R. (1993). Finance and growth: Schumpeter might be right. Quarterly Journal of Economics, 108 (3), 717-737, https://doi.org/10.2307/2118406.

Laitinen, T., \& Kankaanpää, M. (1999). Comparative analysis of failure prediction methods: The Finnish case. The European Accounting Review, 8(1), 67-92, https://doi.org/10.1080/096381899336159

Lane. W.R., Looney, S.W., \& Wansley, J.W. (1986). An application of the Cox proportional hazards model to bank failure. Journal of Banking \& Finance, 10 (4), 511-531, https://doi.org/10.1016/S0378-4266(86)80003-6

Levine, R. (2005). Finance and growth: theory and evidence. In Philippine Aghion and Steven Durlauf (Ed.). Handbook of economic growth. The Netherlands: Elsevier Science.

Levine, R., \& Zevros, S. (1998). Stock markets, banks, and economic growth. The American Economic Review, 88 (3), 537-558, https://www.jstor.org/stable/116848 
Lev, B. (1973). Decomposition Measures for Financial Analysis, Financial Management, Spring (1973), 36-63, https://doi.org/10.2307/3665101

Lindgren, C.J., Garicia, G., \& Saal, M.I. (1996). Bank soundness and Macroeconomic Policy. International Monetary Fund.

Long, S. J. \& Freese, J. (2003). Regression models for categorical dependant variables using Stata. College Station, Texas: A Stata Press Publication.

Maddala, G.S., \& Lahiri, K. (2009). Introduction to econometrics. West Sussex, England: John Wiley \& Sons Ltd.

Mannasoo, K., \& Mayes, G.D. (2009). Explaining bank distress in Eastern European transition economies. Journal of Banking and Finance, 33 (2009), 244-253, https://doi.org/10.1016/j.jbankfin.2008.07.016

Martin, D. (1977). Early warning of bank failure: a logit regression approach. Journal of Banking and Finance, 1, 249-276, https://doi.org/10.1016/0378-4266(77)90022-X

Merton, R.C. (1974). On the pricing of corporate debt: The risk structure of interest rates. The Journal of Finance, 29 (2), 449-470, https://doi.org/10.2307/2978814

Merton, R.C., \& Bodie, Z. (2005). Design of financial systems: towards a synthesis of function and structure. Journal of Investment Management, 3 (1), 1-23.

Meyer, P.A., \& Pifer, H. W. Prediction of bank failures. Journal of Finance, 25 (4), 853-868. https://doi.org/10.2307/2325421

Monin, P. \& Jokipii, T. (2010). The impact of banking sector stability on the real economy. Swiss National Bank Working Papers. Retrieved from http://www.snb.ch.

Morck, R., Yavuz, M.D., \& Yeung, B. (2011). Banking system control, capital allocation and economy performance. Journal of Financial Economics, 100 (2), 264-283, https://doi.org/10.1016/j.jfineco.2010.12.004

Myers, S.C. (1977). Determinants of corporate borrowing. Journal of Financial Economics, 5 (2), 147-175, https://doi.org/10.1016/0304-405X(77)90015-0

Odom, M. D. and R. Sharda. (1990): A neural network model for bankruptcy prediction. Proceedings of the International Joint Conference on Neural Networks II:163-167.

Ohlson, J.A (1980). Financial ratios and the probabilistic prediction of bankruptcy. Journal of Accounting Research, 18 (1), 109-131, https://doi.org/10.2307/2490395

Pettaway, R.H., \& Sinkey, J.F. (1980). Establishing on-site bank examination priorities: an early warning system using accounting and market information. The Journal of Finance, 35 (1), 137-150, https://doi.org/10.1111/j.1540-6261.1980.tb03476.x

Rahman, S., Tan, L.H., Hew, O.L., \& Tan, Y.S. (2004). Identifying financial distress indicators of selected banks in Asia. Asian Economics Journal, 18 (1), 45-57, 
https://doi.org/10.1111/j.1467-8381.2004.00181.x

Rajan, R.G., \& Zingales, L. (1998). Financial dependence and growth. The American Economic Review, 88 (3), 559-586, https://www.jstor.org/stable/116849

Rosli, F. (2012). Malaysian economy in 2012: risks and rewards?. Institute of Strategic and International Studies Malaysia. Retrived from http://www.isis.org.my.

Ross, S.A., Westerfield, R.W., Jordan, B.D., \& Jaffe, J. (2007). Corporate finance: Core principals and applications. McGraw Hill.

Sanya, S. O., \& Wolfe, S. (2010). Can Banks in Emerging Economies Benefit from Revenue Diversification? Journal of Financial Services Research, 40 (1), 79-101, https://doi.org/10.1007/s10693-010-0098-z

Schaeck, K. \& Čihàk, M. (2007). Banking competition and capital ratios. International Monetary Fund Working Paper WP/07/216. Retrieved from http://www.imf.org.

Scott, J. (1981). The probability of bankruptcy: A comparison of empirical prediction and theoretical models. The Journal of Banking and Finance, 5(1981), 317-344, https://doi.org/10.1016/0378-4266(81)90029-7

Shen, C., Hsieh, M. (2003). Prediction of bank failures using combined micro and macro data. National Cheng Chi University \& Meng-Fen Hsieh of Van Nung Institute of Technology.

Shin, K.S., \& Lee, Y.J (2002). A genetic algorithm application in bankruptcy prediction modeling. Expert systems with applications, 23(1), 321-328, https://doi.org/10.1016/S09574174(02)00051-9

Shumway, T. (2001). Forecasting bankruptcy more accurately: A simple hazard model. Journal of Business, 74(1), 101-125, https://doi.org/10.1086/209665

Sinkey, J.F. (1975). A multivariate statistical analysis of the characteristics of problem banks. The Journal of Finance, 30 (1), 21-36, https://doi.org/10.2307/2978429

Takatoshi, I., \& Yuko, H. (2007). Bank restructuring in Asia: crisis management in the aftermath of the Asian financial crisis and prospects for crisis prevention. The Research Institute of Economy, Trade and Industry discussion paper series 07-E-039. Retrieved from http://rieti.go.jp/en.

Taran, Y. (2012). What factors can predict that a bank will get in trouble during a crisis? Evidence from Ukraine, Master's dissertation. Kyiv School of Economics.

Thomson, J.B. (1991). Predicting bank failures in the 1980s. Federal Reserve Bank of Cleveland. Retrieved from http://www.clevelandfed.org.

Vilen, M. (2010). Predicting failures of large U.S commercial banks (Master's thesis). Retrieved from http://epub.lib.aalto.fi/fi/, Aalto School of Economics.

Walker, M.C., Stowe, J.D. \& Moriarity, S. (1979). Decomposition analysis of financial 


\section{Macrothink}

Asian Journal of Finance \& Accounting

ISSN 1946-052X 2019, Vol. 11, No. 1

statements. Journal of Business Finance \& Accounting, 6 (2), 173-186, https://doi.org/10.1111/j.1468-5957.1979.tb01082.x

Whalen, G. (1991). A proportional hazards model of bank failure: an examination of its usefulness as an early warning tool. Economic Review, 27 (1), 21-32.

Yee, C.F. \& Tan, A.E.C. (2009), Banking sector stability and financial liberalization: some evidence from Malaysia. Canadian Economics Association. Retrieved from http://economics.ca.

Yeoh, P. (2009). Causes of the global financial crisis:learning from the competing insights. International Journal of Disclosure and Governance, 7 (1), 42-69, https://doi.org/10.1057/jdg.2009.18

Zmijewski, M.E. (1984). Methodological issues related to the estimation of financial distress prediction models. Journal of Accounting Research, 22 (1984), 59-82, https://doi.org/10.2307/2490859

\section{Copyright Disclaimer}

Copyright for this article is retained by the author(s), with first publication rights granted to the journal.

This is an open-access article distributed under the terms and conditions of the Creative Commons Attribution license (http://creativecommons.org/licenses/by/3.0/). 